\title{
Exploration of E-Commerce Talents Training Mode Based on CDIO-OBE Concept
}

\author{
Gongwen Xu, Lin Shi, Peng Xiao and Zhijun Zhang
}

\section{ABSTRACT}

The rapid development of E-commerce requires the cultivation of welleducated E-commerce talents. However, the traditional talents training methods of E-commerce specialty in colleges cannot meet the requirements of the industry. In order to cultivate high-quality Ecommerce innovative talents, we should keep up with the pace of the times, timely adjust the training scheme, establish a perfect training system and improve the training mode. Based on the main problems existing in the cultivation of E-commerce talents in colleges, this paper introduces the CDIO-OBE engineering education mode. Taking CDIO as the main line of E-commerce specialty courses, the target ability indicators and professional knowledge are gradually run through in all teaching links, cultivating students' practical application ability and improving students' innovative designing ability. Under the concept of $O B E$, the industry requirements are transformed into the ability training objectives of students at different levels, so as to guide the formulation of curriculum training objectives and improve the teaching contents. The two concepts complement each other and jointly improve the current training mode of application talents of E-commerce, so as to cultivate innovative talents of E-commerce with sound vocational skills and professionalism.

Keywords: CDIO, Curriculum system, E-commerce, OBE.
Published Online: August 21, 2021

ISSN: $2736-4534$

DOI :10.24018/ejedu.2021.2.4.156

\section{Gongwen Xu*}

Shandong Jianzhu University, Jinan, SD, China.

(e-mail: xugongwe@163.com)

Lin Shi

Shandong Jianzhu University, Jinan, SD, China.

(e-mail: sdshilin ${ }^{\circledR}$ sdjzu.edu.cn)

Peng Xiao

Shandong Jianzhu University, Jinan, SD, China.

(e-mail: xiaopeng@sdjzu.edu.cn)

Zhijun Zhang

Shandong Jianzhu University, Jinan, SD,

China.

(e-mail: zhangzj@ ${ }^{\circledR}$ sdjzu.edu.cn)

*Corresponding Author

\section{INTRODUCTION}

E-commerce is an interdisciplinary specialty with fast knowledge renewal. These major aims to cultivate students who master vocational skills solidly and have rich management experience [1]-[3]. Students need to learn vocational skills such as E-commerce, economic management, computer network, information technology and so on. Students should not only master some written theoretical knowledge, but also need to integrate theoretical knowledge into practice. They also should have management and team cooperation ability and have high comprehensive professionalism. They can engage in website design, website construction and maintenance, marketing planning of enterprise goods and services, customer relationship management, E-commerce project management, planning and operation of E-commerce activities in enterprises and institutions [4].

There are about more than 100,000 E-commerce graduates joining all kinds of companies from universities and higher vocational colleges every year. Even so, compared with the huge personnel demand of E-commerce, the counterpart employment rate of E-commerce specialty is only about $20 \%$, which is far lower than the average level. Most graduates are engaged in the work which is unrelated to E-commerce. There are great deficiencies in the traditional training mode of E-commerce specialty. E-commerce specialty has also been listed as a yellow card warning specialty by Chinese Ministry of Education. Cultivating application talents of Ecommerce has become an inevitable requirement for colleges to serve the society. On the basis of reviewing the existing literatures, this paper puts forward the main problems existing in the training of E-commerce talents in colleges, introducing the CDIO-OBE engineering education mode to construct the training mode of application talents in E-commerce. Organizing, implementing, and evaluating education mode based on expected learning outcomes, so as to jointly improve the current training mode of application talents of Ecommerce.

\section{PROBLEMS IN THE TRAINING OF E-COMMERCE TALENTS}

At present, there are the following problems in the training of E-commerce talents.

\section{A. Teachers' Practical Experience is Insufficient, and Teaching Methods are Outdated}

At present, E-commerce specialty teachers are mainly doctors or masters graduated from colleges. They have solid theoretical knowledge, but they are lack of enterprise practical experience and specific practical operation ability. Their teaching is easy to favor theory but short of project practical training. So, the skilled teachers should be 
introduced into colleges and some teachers should be sent to enterprises to participate in practice.

\section{B. The Teaching Objectives are Inconsistent with the Market Requirements}

With the popularity of the Internet, the development of Ecommerce in China is entering a new stage with intensive innovation and rapid expansion. Despite the rapid development of the E-commerce industry, college teachers are short of enterprise practical experience. At present, the combination of the training content of E-commerce specialty with the job requirements of enterprises is not sufficient. Many teachers cannot grasp new technologies, new ideas and new tools firmly, so it is difficult for them to complete the teaching objectives in the professional training courses.

C. The Teaching Content is Complex, and Students Lack Initiative and Innovative Learning

In addition to the basic knowledge of E-commerce specialty, the teaching content of E-commerce specialty also involves network marketing, E-commerce platform construction, E-commerce data analysis, customer relationship management and another related knowledge. Therefore, for such courses, it is difficult to carry out teaching in college education according to conventional teaching methods. If the knowledge of the courses is just simply superimposed, it has little practical significance for students to improve their professional skills. The above problems lead to students' low enthusiasm for learning the courses and the lack of innovation in the curriculum.

\section{Lack of Distinctive Curriculum Content and Curriculum System}

The existing curriculum content and curriculum system in colleges basically make a few changes on the curriculum system issued by the Ministry of Education, and do not form their own characteristics according to their school features. The orientation of each college is different, and its curriculum content and system should not be the same. The curriculum content and system of E-commerce specialty should be organized based on the training objectives of application talents, guided by social needs, based on application characteristics, and combined theory with practice [5].

\section{CDIO AND OBE CONCEPT}

In recent years, CDIO (Conceive, Design, Implement, and Operate) and OBE (Outcomes-Based Education) concept has attracted extensive attention. The core of CDIO concept is to take the actual project as the carrier to let students learn engineering in an active and practical way. OBE is an educational model based on learning outcomes or results, which organizes, implements, and evaluates education centered on expected learning outcomes.

CDIO is a systematic reform program in the field of engineering education. CDIO education concept was jointly founded and developed by MIT and several other universities from 2000 to 2004 . The concept takes product R \& D and product life cycle as the carrier, and guides students to improve their scientific and technological literacy through the organic combination of active and practical courses [6].

The vision of CDIO is to provide students with engineering skills education based on engineering design background and build the whole process of product and system conceive, design, implement and operate based on the real world. The CDIO concept outlines the basic engineering knowledge, personal ability, practical ability, team ability and overall CDIO processing ability of engineers for the first time, so as to make the engineering education reform have a clear purpose. In order to solve the problem of emphasizing theory over practice in traditional teaching and improve students knowledge level and comprehensive quality and ability through practical training. CDIO is a systematic, scientific, and advanced entity, representing the development direction of contemporary engineering education. Under the guidance of CDIO education concept, the new teaching model emphasizes "learning by doing" and project-based "learning and teaching". CDIO takes the life cycle of engineering projects from $\mathrm{R} \& \mathrm{D}$ to operation as the carrier. Its core idea is to conduct practical teaching as close to the actual engineering design projects as possible, guide students to learn actively, and realize the organic integration of theory, practice, and innovation in teaching [7].

OBE can also be called ability-oriented education, goaloriented education or demand oriented education. It was put forward by Spady et al. in 1981. As an advanced educational concept, it has become the mainstream concept of educational reform in the United States, Britain, Canada, and other countries. Its core idea is that educators have a clear idea of the ability and level that students should have achieved when they graduate. OBE education concept takes students as the center and takes the ability that students should have when completing the project as the starting point to organize and implement the whole process. The starting point is not what teachers want to teach, but what is needed to achieve the final ability that students should have. That is, the focus is not on what students know, but on what students can do. OBE model takes the expected learning outcomes as the center to organize, implement and evaluate education. In the OBE education system, educators ought to have a clear vision of the abilities and levels that students should achieve when they graduate, and then design appropriate educational structures to ensure that students achieve these expected outcomes. Educational structures and courses are regarded as means rather than targets [8], [9].

\section{COnStruction OF E-COMMERCE TEACHING FRAMEWORK}

E-commerce is an interdisciplinary specialty. In the course construction, we should effectively combine the course contents of these related subjects. It should be based on the training goal of application talents, guided by social needs, with application characteristics as the main line, and the combination of theory and practice. When formulating the teaching plan of E-commerce specialty, we need to actively investigate it, fully demonstrate it and accurately locate it, so as to highlight the training characteristics of E-commerce talents.

We should develop the characteristics of E-commerce specialty, promote the all-round development of students, and improve the quality of undergraduate talents training. The training characteristics of E-commerce specialty are to 
cultivate high-quality, application-oriented, and practiceoriented talents. It mainly improves students' operation skills and accumulates practical experience through the combination of school and enterprise, project driven and industry university research.

The CDIO-OBE concept emphasizes that the school should cultivate what kind of talents that the enterprise needs. Therefore, the school should cooperate with enterprises to effectively solve the problems in the operation of Ecommerce enterprises and allow students to participate in them, which not only solves the practical problems of enterprises, but also cultivates students' practical ability [10][12].

Students are organized to practice in various enterprises in their spare time to truly experience the business interaction process in the operation. For example, Students go to major retail enterprises, E-commerce enterprises and other enterprises with extensive application of network technology to participate in enterprises' E-commerce business activities.

Schools and enterprises carry out "embedding mode" talent training, embedding the enterprise's requirements into the talents training program, and jointly train E-commerce talents based on the current needs of enterprises rather than the needs of schools.

The reform of talent training mode in colleges is a systematic project. The concept of outcomes based education (OBE) emphasizes how to take social needs as the criteria for talent training objectives, and then complete the formulation of talent training scheme through conceive, design, implement and operate (CDIO), so as to meet the needs of Ecommerce industry [13]-[15].

The excellent E-commerce operation talents should be compound talents with innovation, market sensitivity and practicality. They have the ability of market research, are familiar with the behavior and psychology of online consumers, master network tools such as social media and search engines, and have vocational skills such as planning, design and implementation of network integrated operation.

Combined with the current demand of E-commerce for talents and their skills, combined with the research results of colleges at home and abroad, this paper puts forward the technical path of E-commerce teaching reform based on CDIO-OBE concept, as shown in Fig. 1.

1) Based on the OBE concept, through research and literature analysis, we have transformed the ability demand of the industry for E-commerce talents into the ability training goal of E-commerce talents, so as to ensure the strict matching between the industry demand and the training goal.

2) Based on the goal of E-commerce ability training, we reverse design the curriculum system. Firstly, according to the demand of talents ability training objectives, we allocate the ability training objectives of each course, and then reasonably allocate the required theoretical knowledge points into each relevant theoretical course according to the teaching needs, so as to establish the supporting relationship between theoretical courses and practical courses.

3) Guiding the teaching process of the course with CDIO concept, we should develop projects that meet the training objectives of the course, design teaching contents, integrate relevant knowledge points of practical skills and theories, and fully cultivate students' ability to use theoretical knowledge for E-commerce practice.

4) Through the evaluation of teaching effect, we should continuously improve the ability training objectives and E-commerce curriculum framework.

5) Popularizing and applying the above theories and methods.

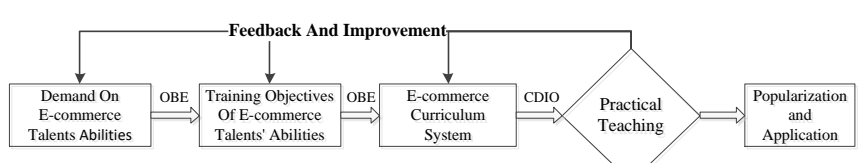

Fig. 1. The teaching framework based on CDIO-OBE concept.

\section{COnstruction OF E-COMMERCE TEACHING System}

\section{A. Construction Ideas}

To build an E-commerce teaching system under the concept of CDIO-OBE, we should firstly realize the transformation from courses education to target education. It should be based on social and market needs. It should not only consider the initial job requirements of graduates, but also pay attention to the ability requirements of students in subsequent career development to meet sustainable development. In this paper, the CDIO-OBE concept is applied to the construction of the teaching system of Ecommerce specialty. It emphasizes student-centered and aims at the ability that students should achieve four years after graduation. That is, the E-commerce innovative talents not only have high standard practical ability, but also have good team communication and writing ability, and can better complete the work of expression and report writing [16].

Guided by this ability goal, we design practical teaching, introduce project-based teaching, establish a diversified assessment system, and evaluate the practice process and learning output results according to the teaching goal, so as to form a teaching system based on CDIO-OBE, as shown in Fig. 2.

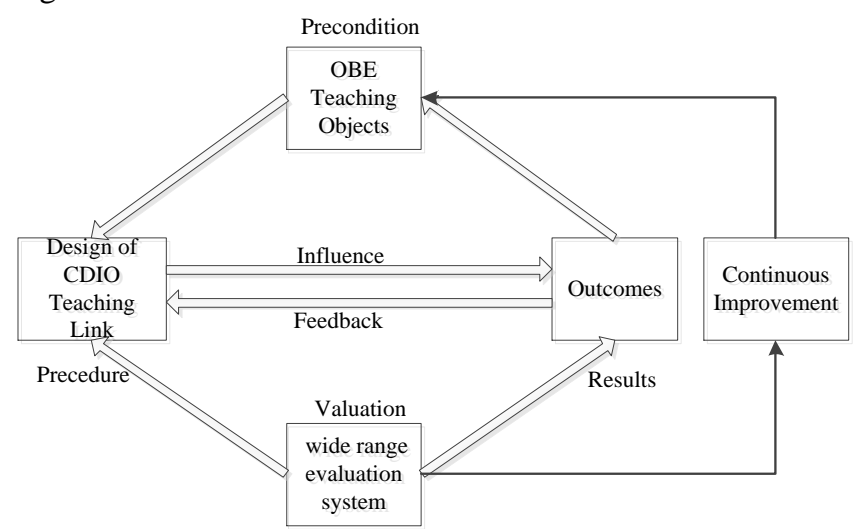

Fig. 2. The teaching system based on CDIO-OBE concept.

\section{B. Construction Process}

The CDIO project-based teaching is a key link in the implementation of E-commerce teaching. Under the guidance of CDIO concept, taking the project as the main line and students as the main body, connect the original fragmented curriculum content into lines and then expand to areas, so as to realize the progressive improvement of students' 
innovation ability and comprehensive quality in the complete teaching process. According to the cultivation of students' ability at different levels, the curriculum items are divided into three categories: basic content, in-class comprehensive curriculum and out-of-class comprehensive curriculum. For the basic courses content, it mainly takes the content of teaching materials as the carrier, adopts various teaching methods and means to stimulate students' interest and cultivate students' practical ability hands-on operation ability. After the basic course content is completed, the in-class comprehensive curriculum is introduced, which mainly focus on specialized coursess, mainly exercise students' comprehensive ability with the help of course design. Then students can be familiar with business processes, learn to comprehensively use various knowledge and cultivate their comprehensive ability. In the out-of-class comprehensive curriculum, relying on teachers' scientific research projects and based on the integration of science and education, cultivate students' innovative design ability, so as to build a progressive teaching mode and cultivate students' abilities step by step. Every teaching unit, curriculum design and scientific research project has gone through the whole process of conceive, design, implement and operate (CDIO). The students can experience the overall process from theory to practical application, from scheme to implementation.

OBE concept focuses on outcomes, and finally emphasizes students' application and practical ability through learning. Ecommerce specialty cultivate talents with good E-commerce application ability and comprehensive quality to meet the needs of social and market development. Therefore, the setting of curriculum teaching objectives should also clearly reflect the support for graduates' abilities. The teaching goal of E-commerce specialty is clearly refined into the ability training goal of students at different levels, which not only enables students to master basic practical ability, such as office software operation skills, but also cultivate students' comprehensive design ability and innovation ability, so as to realize the goal of building a progressive teaching system and gradually cultivating students' abilities.

\section{ANALYSIS OF TEACHING EFFECT}

We investigated two groups of students. One group received this teaching reform program based on CDIO-OBE concept, and the other group did not receive this program. The learning effect of these two groups of students was assessed. In the assessment process, the following five dimensions of teaching objectives are designed.

1) Basic knowledge: students should understand Ecommerce and its business knowledge and processes such as planning, design and operation;

2) Various skills: students are able to flexibly use the skills learned in the previous courses, such as online store construction and decoration, image processing, web page production, network construction, etc.;

3) Teamwork: students should master the ability to jointly operate the E-commerce platform through teamwork;

4) Operation module: students should use the basic knowledge of operation to carry out content operation, activity operation and customer operation;

5) Innovation ability: students should have certain information processing, quantitative decision-making and innovative application ability.

According to the assessment items and results designed based on the teaching objectives and the average scores of the assessment of each course, the final achievement degree of the learning effect was obtained, as shown in Fig. 3.

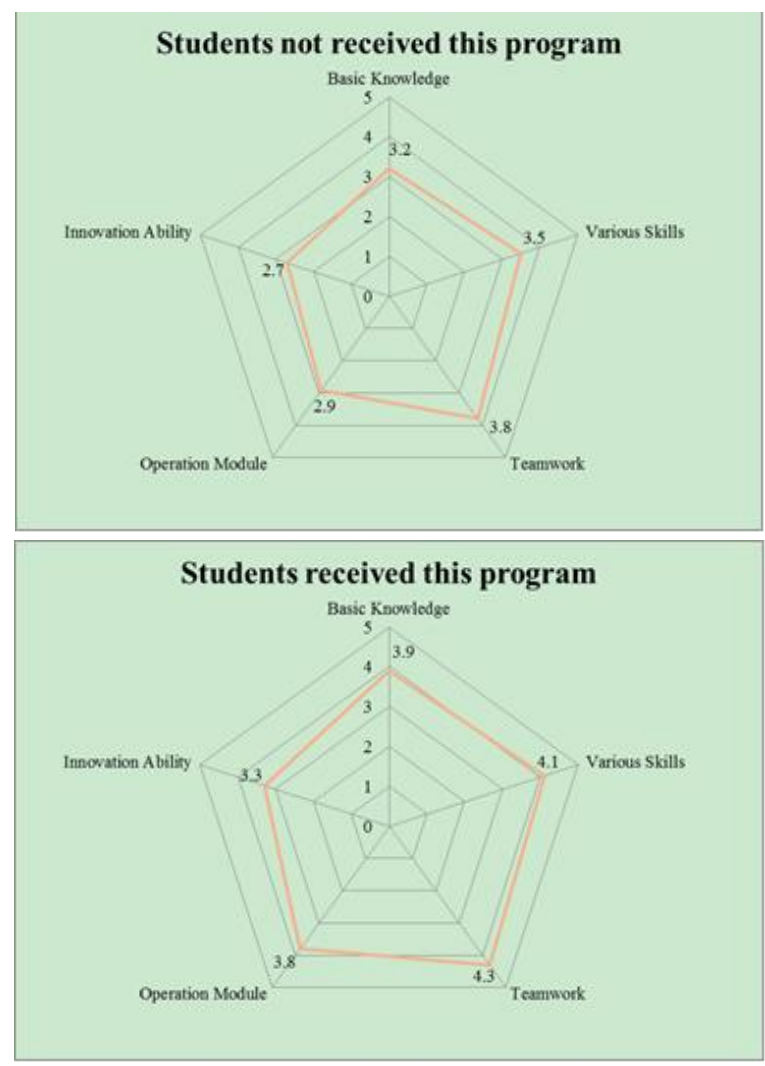

Fig. 3. Radar chart of learning effectiveness.

It can be seen from the radar chart that the students who have received the scheme have greatly improved their abilities in all aspects, while the students who have not received the scheme have a lower level, especially in the practical ability such as operation module.

According to the teaching effectiveness and radar chart, it is suggested that the construction of E-commerce courses group should face the development trend of the Internet industry, formulate the customized growth channel of CDIOOBE, and combine it with the actual situation of students. For example, the courses can be grouped into the following directions: Internet product planning direction, Internet product customer experience design direction, Internet product operation direction. We should teach students in accordance with their aptitude and situation, and guide students to combine their employment direction with their course design projects and even graduation design. At the same time, in the project practice, we should pay attention to the project process monitoring, help students plan their knowledge, skills and talents, and lay a good foundation for students' graduation design and work in the future.

\section{CONCLUSION}

CDIO-OBE engineering education model consists of CDIO and OBE, in which CDIO is the means and OBE is the target, and they complement each other. The introduction of 
CDIO-OBE engineering education mode can overcome the current problems of emphasizing theory but neglecting practice, short teaching hours, disconnection between experimental content and engineering practice, backward assessment methods and so on, improve students' initiative, and it is conducive to the development of students' innovation consciousness and comprehensive quality.

Cultivating talents with innovative design ability and comprehensive quality is the core goal of the construction of E-commerce specialty. By exploring the construction of Ecommerce specialty teaching system under the concept of CDIO-OBE, this paper defines the curriculum training goal focusing on the cultivation of students' ability at different levels. Guided by the goal, reverse design the curriculum framework and system, run through the whole curriculum teaching process with project-based teaching, build a multilevel progressive practice teaching mode, which could gradually cultivate students' practical ability.

\section{ACKNOWLEDGMENT}

This work was supported in part by the Shandong Education Department Teaching Reform Project (Z2016M014, Z2016M016, Z2016Z013, M2018x197), the research project of China Association of Construction Education(2017063).

\section{REFERENCES}

[1] Liu, Y., X Zhang, and Q. Zhou, "VR Technology Online Classroom Mode in Cross Border E-Commerce Teaching in Colleges and Universities," IEEE Access PP.99(2020):1-1.

[2] Deng, J., and H. Qing, "Innovation of Cross-border E-commerce Practice Teaching Based on Big Data," Journal of Physics: Conference Series, 1852.2(2021):022010 (6pp)

[3] Ca O, W. G., X. Y. Wang, and C. Y. Chen, "Studying on the ECommerce Teaching Simulation System," Journal of Industrial Engineering and Engineering Management, 16.3(2002):13-17.

[4] Jian-Hua, H. E., "On the Innovation of E-commerce Teaching Model Based on the Cultivation of Innovation and Entrepreneurship Ability," Journal of Zunyi Normal University, (2019).

[5] Wang, Y., "Teaching Reform Practice of E-Commerce Major Integrating Specialty and Entrepreneurship," 2020 International Conference on E-Commerce and Internet Technology (ECIT) IEEE, 2020.

[6] Gongwen Xu, Jing Wang, Zhijun Zhang, "Exploration and Research on Cultivating Innovative Students of E-commerce Based on CDIO Concept,” BF-PSS 2017. Sapporo, Japan. Dec.29, 2017.

[7] XU, Gong-wen, et al. "Exploration and Practice of Generic Cabling Practical Project with Collaborative Innovation Idea Based on the CDIO Pattern," Research and Exploration in Laboratory, 2016.05:231-235.

[8] Chen, Wei-Ping, et al., "Exploration and practical research on teaching reforms of engineering practice center based on 3I-CDIO-OBE talenttraining mode," Computer Applications in Engineering Education 29.1 (2021): 114-129.

[9] Yue, J. I. A., W. E. N. Yan-dong, and W. A. N. G. Xing-hui, "Research on the Formulation Method of Higher Vocational Professional Training Program under the OBE-CDIO Concept," $201914^{\text {th }}$ International Conference on Computer Science \& Education (ICCSE). IEEE, 2019:868-871.

[10] Ce, Ji, "Exploration and Practice in the Teaching Course of "Signal and System" based on OBE-CDIO Education Concept [J]," Journal of educational institute of jilin province, 2 (2018): 118-121.

[11] Xiaoling, Xu, Liu Mei, and Huang Jianfeng, "Exploration of Measurement and Control Technology and Instrumentation Training Program Based on OBE-CDIO," China Modern Educational Equipment, (2016): 09.
[12] Jin, Haiyi, “A Case Study of OBE-CDIO Implementation in Network Planning and Design Course," $201914^{\text {th }}$ International Conference on Computer Science \& Education (ICCSE). IEEE, 2019:331-334

[13] Li, Yao, et al., "Reform of Database and Data Warehouse Course Based on OBE-CDIO Model," International Conference on Machine Learning and Big Data Analytics for IoT Security and Privacy,Springer, Cham, 2020:724-730.

[14] Yue, Jia., 'On OBE-CDIO into Inquiry Teaching Reform.” $201813^{\text {th }}$ International Conference on Computer Science \& Education (ICCSE), IEEE, 2018:1-5.

[15] Lin, Zhenwei, et al., "Exploration of BIM Teaching Reform in Civil Engineering Specialty Based on OBE-CDIO Concept," Journal of Information Technologyin Civil Engineering and Architecture, 13.2 (2021): 36-43.

[16] Sun, Minghong, "A Research on OBE-CDIO Finance Education Reform Under the Age of Big Data," $2^{\text {nd }}$ International Conference on Education, Management Science and Economics (ICEMSE), 2017. 